Journal

of Geography,

Politics and Society

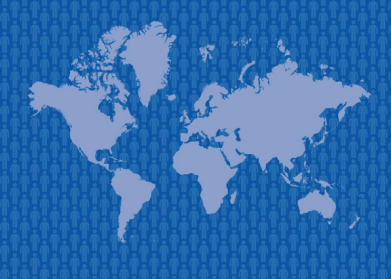

$10(4) / 2020$

\section{Journal of Geography, Politics and Society}

2020, 10(4), 1-7

https://doi.org/10.26881/jpgs.2020.4.01

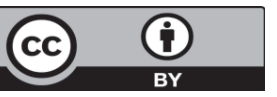

\title{
TRANSFORMATION OF THE CONDITIONS OF SOCIO-ECONOMIC DEVELOPMENT OF AZERBAIJAN IN THE POST-PANDEMIC PERIOD (BY SEPTEMBER 2020)
}

\author{
Ismayilov Chingiz \\ Department of Economic and Social Geography, Baku State University, Academician Zahid Khalilov 23, Az 1148 Baku, Azerbaijan. \\ e-mail: ischingiz@gmail.com
}

\section{Citation}

Chingiz I., 2020, Transformation of the conditions of socio-economic development of Azerbaijan in the post-pandemic period (by September 2020), Journal of Geography, Politics and Society, 10(4), 1-7.

\section{Abstract}

The global economic crisis and the spread of the pandemic virus in a short period have radically changed the world around people. The curtailment of production, the closure of different kinds of services, self-isolation, and the distribution of virtual contacts has become characteristic in the state of almost every country. Depending on the level of socio-economic development, not all countries are equally experiencing this difficult period of crisis in modern civilization. The spread of COVID-19 and the global economic crisis, accompanied by a sharp drop in oil prices, have had a significant impact on the socio-economic condition of the oil exporting countries. Azerbaijan, such a country facing these emerging problems, has taken steps to prevent the spread of the pandemic beyond the metropolitan region. Thanks to a balanced fiscal and monetary policy of the government, as well as the availability of sufficient foreign exchange reserves, the negative impact of the above factors has been minimized. The implementation of the oil strategy of the republic has created favorable conditions for the development of the non-oil sector of the economy. Participation in international transport and logistics projects contributed to the development of inter-district and intra-district transport infrastructures. An extensive network of transport and communication systems has favored the economic development of the regions of the republic. Despite the changing conditions of social economic development of the country, the process of creating infrastructure facilities continued. Of course, the new conditions have adjusted the implementation of state programs for the construction of new economic and socially significant facilities. Large financial deductions from the sovereign Oil Fund of the republic allowed for the shortest possible time to put into operation mobile hospitals, enterprises for the production of medical masks, as well as subsidies to support small and medium enterprises. The new picture more actualizes the development of the non-oil sector of the economy, especially the agricultural sectors. With this in mind, when developing a new strategy for the future development of the republic, one should take into account the lessons of the occurrence of previously unforeseen risks. This will mitigate the blow of new possible cataclysms and get out of the crisis situations with the least social and economic losses.

\section{Key words}

transformation conditions, economic development, post-pandemic period, oil industry, Azerbaijan. 


\section{Introduction}

The ongoing processes of globalization are expanding the area of human activity, which largely depends on the level of development of interstate economic contacts. The extensive network of international logistics infrastructure has played an important role in the growth of human mobility. Due to the high pace of development of population mobility, a process of "compression" of the area and its accessibility in time was taking place. The acceleration of trade operations and the interchange of goods have gradually changed the picture of perception of the scale of the area. Due to the expansion of the transport communications network and the transport accessibility of the territory, practically of any place on the earth, people gradually ceased to objectively evaluate in reality the scales of extending areas. Of course, as in life, at a high speed of movement, it is difficult to evaluate the scale of the area surrounding us, and only by stopping, we can "see" the world around us in reality close to the truth. All of the above can be projected onto our world today, in the context of a growing, and still completely incomprehensible to us, global economic crisis, coupled with the ubiquitous spread of the COVID-19 virus pandemic.

The spread of the pandemic in almost all countries of the world has made it necessary to conduct relevant research. Scientific publications considered the development of epidemiological models and the medical aspect of the issue (Galvani et al., 2003; Gumel et al., 2004; Lipstich et al., 2003; Wang et al., 2006; Yu et al., 2007) and also analyzed the impact of the pandemic on all aspects of public life (Brief\#2:..., 2020; Keogh-Brown et al., 2010; Kneips, 2020; Nicola, 2020, Wilson, 2020). Analysis of these publications showed that there is no definite answer to the duration of the period of the spread of the disease.

The development of economic relations of Azerbaijan, both with neighboring countries and with distant foreign countries, has largely become possible thanks to a balanced foreign policy, implementation of oil strategy programs and the consistent realization of effective measures for the social economic development of the country. The gradual increase in the level of well-being of the population of the country contributed to the expansion of the geography of international relations of the republic. A comparative analysis of the features of the socio-economic development of the republic with neighboring countries, as well as with countries where the oil industry plays a decisive role in their economic development, revealed certain similarities and differences in the strategies for transforming their economy. So, what are the features of the transformation of the conditions of socio-economic development of Azerbaijan in this challenging and unpredictable period of the spread of the COVID-19 virus pandemic?

\section{The value of area is changing, the structure of the economy is being transformed, and the importance of suburbanized zones is growing}

The current conditions of loosening the foundations of the sustainability of the global economy are determined by the revision of certain provisions of the views of the founder of modern economic science, Milton Friedman, who believed that the most important locomotive of economic development is to ensure profit. Obviously, it is necessary to take into account the cardinal nature of changing the configuration of the functioning area of the world economic system. Gradually, features of the fragmentation of the global economic area began to emerge. Most countries have begun to implement measures to ensure their economic security. For this purpose, a number of countries began to close their borders and temporarily nullified all types of economic ties. Those countries that, contrary to the spread of the pandemic, continued to maintain economic relations faced the emergence of foci of the spread of the virus primarily in the border areas.

The spread of the pandemic revealed at first glance the loss of the threat of the nationalistic aspirations of the developed countries to maintain their advantages, due to years of established privileges in solving international political and economic problems of the world. Creation of various political and economic alliances, with the involvement of developing countries, created the illusion of the complete erasure of the characteristic features of nationalism. The globalization processes of "blurring" of the borders as if became an additional confirmation of these shifts. However, the migration processes of the population, increase of financial and economic crises, the uneven socio-economic development of individual countries within the union associations, clearly showed the fragility of the created union structures. An example of the beginning of such processes was the British exit from the EU (Brexit). Fundamental disagreements between the EU member states on the issues of refugee acceptance, distribution of financial resources, structural reforms and other issues have become the prerequisites for shattering the EU's foundations. The desire to impose the vision on the implementation of reforms and future development strategies, without taking into account 
the particularities of the development of each country, has caused concern among potential candidates who have been trying to become EU members for many years. An example of this is Turkey, which no longer seeks to claim this role. Disappointment in the EU is also evident from some participants in the "Eastern Partnership with the EU" program. In particular, Azerbaijan, in accordance with its national interests, within the framework of the proposed projects, expressed its desire to re-discuss certain provisions of cooperation with the EU.

The spatio-temporal scale of the spread of the virus pandemic plunged the world community into global shock. Most of all this was felt by people employed in the service sector. In this regard, countries with the dominant share of the service sector turned out to be a kind of hostages of the situation, where this sphere of human activity during the period of strict self-isolation to a large extent became unclaimed. As a result, the social situation of people in the service sector has sharply worsened. Taking into account the growth rates of this industry, one can imagine the consequences of economic damage to the global economy. "According to the World Bank (WB), the average share of the services sector in the structure of the world's GDP from 1997 to 2019 increased from $50 \%$ to $55 \%$. The largest economies of the G20, whose total share in world GDP by the end of last year amounted to $78 \%$, have significant differences in the distribution of sources of wealth: in the same period, the service sector expanded from $57 \%$ to $62 \%$, and the share of the "real" economy dropped below 40\%" (Zelcer, 2020). In leading industrialized countries, the share of the service sector varies between $65-77 \%$. One can imagine what the consequences of the spread of COVID-19 will be for Macau and Hong Kong, where the share of the service sector in GDP is $94 \%$ and $89 \%$, respectively. According to a number of experts (Bloom, 2020), a pandemic and economic downturn in the entertainment industry alone over the course of 5 years will cost $\$ 160$ billion.

In contrast, the changing picture of international economic relations most clearly showed the importance of the real economy. It is known that the development of the service sector characterizes the growth of social welfare. However, without the development of the real economy it is impossible to ensure the sustainable development of the country; therefore, it is very important to implement measures to promote the development of this sector of the economy. Paradoxically, the threat of a possible shortage in the supply of food to the population has put on the agenda a review of the issue of ensuring food security in each country. The pandemic showed the degree of socio-economic vulnerability of those countries that are most dependent on food imports. Therefore, a full use of the natural resource potential, with the aim of developing the agricultural sector, will contribute to solving the problems of ensuring the food security of the country. It is known that each country usually has its own weaknesses that determine their vulnerability in the case of economic crises and new challenges. In the South Caucasus region, economic development largely depends - in Azerbaijan on export of hydrocarbon raw materials, in Georgia on the development of the tourism sector, in Armenia - on external financial borrowings. All of these sectors were mostly affected by the current crisis. The volatility of oil prices hardly surprises anyone, and the restoration of the tourism industry and attracting potential investors is a more complex and time-consuming process. Therefore, the exit of the countries of the region from the state of recession will require a longer time.

Having a sufficient volume of its foreign exchange reserves, Azerbaijan continues to implement the next state program for the development of regions, with the aim of putting into operation new stations for power supply of peripheral zones and developing a network of transport infrastructure in districts of the republic remote from the center. Along with this, the creation of new farms in rural areas contributes to the opening of new jobs, which favorably affects the increase in the attractiveness of rural settlements. Although the economic crisis and pandemic impacted farms, at the same time it attracted the attention of urban residents. The spread of the pandemic in the republic, mainly within the agglomeration of Baku, has become an additional factor in increasing the attractiveness of suburbanized zones. As in many countries, the citizens rushed to the provinces for temporary residence for the period of self-isolation. By the closure of aviation and the practical impossibility of leaving the country for vacations, citizens began to rent cottage housing in suburbanized areas and in mountainous areas of the republic from April-May. A sharp increase in demand in the domestic tourism market led to a corresponding increase in prices in the services sector. According to our calculations, the monthly cost of house renting in the summer cottage area increased by 2-3 times.

The ongoing shifts in the revaluation of the cost of space in rural areas may serve as a new regulator for a more complete and efficient use of the natural resource and human potentials of the regions of the republic. As indicated in the Development concept "Azerbaijan2020: a look into the future" ("Azərbaycan.., 2012), one of the main directions of 
the future development of the country is to promote the development of the non-oil sector of the economy. The current development of transport, construction, tourism and agricultural production, as the leading links in the non-oil sector, play an important role in the socio-economic development of the regions of the republic.

\section{Reconstruction and adaptation to new conditions of socio-economic development}

One can say that the distribution of COVID-19 is becoming a tool for changing people's lifestyles, which is clearly manifested in relation to education, the service sector, recreation and leisure. But most importantly, consumer needs are radically changing, which is reflected in the implementation of financial costs. Therefore, it can already be argued that we are witnessing a paradigm shift in people's lives.

The global economic crisis, plus the spread of the pandemic and, as a result, large-scale measures for self-isolation, will consistently reorient our attitude to the outside world. The satellite images which testify to the improvement of the ecological state of the air in highly urbanized areas of Europe allow us to optimistically assess the natural possibilities of selfhealing of the natural environment. However, the relaxation of quarantine and self-isolation conditions showed the restoration of the previous picture of environmental degradation in the most urbanized zones of developed countries. In view of this, the issue of changing the priorities for the development of resource use was on the agenda. In this direction, Azerbaijan is consistently implementing state programs to promote the development of sectors of the non-oil sector of the economy.

In accordance with the future development strategy of the country, it is envisaged to comprehensively ensure the socio-economic development of the regions and increase the competitiveness of the economy, using the benefits of the economic and geographical position of each region and the available natural and human resources. These goals are reflected in the "Development Concept of Azerbaijan 2020: a look into the future", which was approved by the Decree of the President of the Republic at the end of 2012. The fundamental direction of the socio-economic development of the republic was to promote the development of industries in the regions of the republic and ensure growth through the introduction of innovative technologies. Thanks to the support of the agricultural sector, viticulture, cotton growing, tobacco growing, grain growing, sugar beet production, and others began to revive.
The main goal of the Concept was to increase the gross domestic product in the republic by twofold by 2020 , mainly due to the development of the nonoil sector ("Azərbaycan.., 2012). However, the next global economic crisis in 2014-2015 and the subsequent volatility of hydrocarbon prices, coupled with the ongoing process of the spread of the pandemic (COVID-19), did not allow us to achieve our goals. We should not lose sight of the fact that the oil industry is still maintaining its leading position in the country's GDP structure. As a result, the decline in oil prices, of course, still affects the implementation of state socio-economic programs and the solution of the tasks.

The erupted economic crisis and the pandemic of the virus extremely complicated the conditions for economic reform, the functioning of production processes and the service sector. In order to provide state support to various sectors of the economy, including entrepreneurship, on the basis of an order of the President of Azerbaijan, "On a number of measures to reduce the negative impact of the coronavirus pandemic (COVID-19) and the sharp fluctuations caused by it on the world energy and stock markets, on the economy of the Republic of Azerbaijan, macroeconomic stability, employment issues in the country and business entities", 10 support programs have been developed. The government of Azerbaijan allocated 2.5 billion manat to implement these support programs (The Order..., 2019).

Along with this, protecting the health and ensuring the safety of the population have become an important task in preventing the spread of the virus. We have witnessed how most countries have banned the export of protective medical masks and necessary disinfectants. With this in mind, against the backdrop of the threat of the spread of the dangerous virus, the government has taken steps to eliminate the shortage of medical masks, protective and disinfectant means. So, Laric Chemical launched the production of hand sanitizers in late March, and the production of medical masks was started in Sumgait Chemical Industrial Park in early April. 3.9 million manat ( $\$ 2.2$ million) of investments were spent on the establishment of a medical mask production enterprise, and 1.2 million manat $(\$ 700$ thousand) of soft loans were allocated to the enterprise through the Entrepreneurship Support Fund under the Ministry of Economy of Azerbaijan. The daily production volume is 100,000 masks, and after the opening of the second line, the daily production volume will reach 220,000 . This will fully cover the domestic demand for medical masks. 


\section{Consequences of the interference of the global economic crisis and the spread of COVID-19}

The all-encompassing scale of the spread of the virus has shown the helplessness of even the powerful, i.e. a wealthy, class of society that faced with the intractable tasks of preserving and securing its advantages. Thus, prerequisites arose in leveling the previously deepening trends of social polarization in society. At the same time, the slowdown in the "speed" of people's livelihoods, especially in urbanized areas, gradually revealed the significance and value of everyday things, which had previously been neglected. Having a large length of free time during the period of self-isolation, most people obviously realized the degree of vulnerability of society to such global excesses. Despite advances in healthcare and the growing scale of the introduction of innovative technologies, the global community was unprepared to prevent the planetary spread of the virus. Even countries with a high level of health care development have not been able to prevent the massive spread of the virus and numerous casualties.

The state of the world economy and the indicators of the socio-economic development of most countries by the end of 2020 will certainly be significantly reduced. In individual countries, the magnitude of the decline in GDP will differ significantly from each other, which will be determined by the degree of readiness of the countries for the crisis and the effectiveness of measures taken to curb the spread of the pandemic. According to the World Bank forecasts, in 2020, the economy of the planet is expected to decrease by $5.2 \%$ and this decline will be the deepest since the Second World War, and the decline in per capita production over the period from 1870 will affect the largest share of countries (COVID-19 to Plunge..., 2020).However, perhaps the predicted indicators will turn out to be incorrect since it is still not completely understood when the pandemic will end, and how quickly the world economy will emerge from the state of recession.

According to the State Statistics Committee of the Republic of Azerbaijan for the period of JanuaryMay, the GDP amounted to $27,479.9$ million manat $(16,164.64$ million dollars), which decreased by $1.7 \%$ compared to the same period in 2019. Moreover, the decrease occurred both in the oil and gas and nonoil sectors (within 1.2-2.0\%).

Along with this, the cost of consumer goods and services in the country slightly increased. In the first five months of 2020, inflation in the republic, compared to the previous year, increased by $2.9 \%$ (2020ci ilin yanvar.., 2020). At the same time, in May-June, due to seasonal factors, the growth rate of consumer prices in Azerbaijan began to decline and even slight deflation was observed. However, the signs of stagnation in the economy still make themselves felt, which is manifested in a decrease in the volume of retail trade and the foreign trade turnover of the republic.

Despite all the negative manifestations in public life being the consequences of the spread of the pandemic, countries of the world are struggling with the epidemic with various successes, and they implement a set of necessary measures by taking into account the WHO recommendations. Some communities have dealt with the crisis much better than others. According to Archon Fung (2020), "We might well find that success came in states where government, civic and private-sector leaders joined their strengths together in a spirit of self-sacrifice for the common good".

An example of this is the course of processes in the countries of the South Caucasus. If in Armenia the situation with the spread of the pandemic is depressing, then in Georgia and Azerbaijan it was possible to resolve the issues of minimization of the spread of the virus more successfully, which affected the change in the magnitude of the main economic indicators. In particular, in the first quarter of 2020, GDP in Azerbaijan even increased by $0.2 \%$, and by the beginning of June, as expected, the economy of the republic, as mentioned above, went into a recession. Such dynamism became possible as a result of the effectiveness of measures taken to support entrepreneurship in the republic.

Despite all the complexity of economic difficulties, the government continued to support entrepreneurship in the regions of the republic. Thus, the process of establishing agro, techno-industrial parks, mainly outside the metropolitan area, creates an opportunity for entrepreneurs to use the natural resource potential of the regions, which has been insufficiently used. In the changing economic conditions, it is obviously necessary to reconsider the conditions for attracting potential investors, entrepreneurs and businesspersons to new territorial entities. This is especially true for the Alat free economic zone, located $70 \mathrm{~km}$ south of Baku.

The establishment of the Alat free economic zone near Baku creates favorable conditions for the development of transit railway cargo transportation, which, of course, will increase the attractiveness of the Baku-Tbilisi-Kars railway. This free economic zone, located at the intersection of East-West and North-South transport corridors, will operate as the largest logistics center in the Caspian region. In the near future, due to the interest in the region of 
China, Afghanistan, Pakistan, Central Asia and the Middle East the importance of the international sea trade port of Alat is expected to increase noticeably.

In the development of transport infrastructure and the solution of tasks to stimulate the development of farms and the use the natural resource potential of the regions of the republic will be a positive prerequisite for the establishment of the Lyaki-Gabala railway line. The annual increase in the number of tourists, especially foreigners, in the Gabala zone led to the development of resort and recreational services, which pushed the corresponding development of the service sector. However, as anywhere in the world, the crisis has exposed the vulnerability of national economies mainly focused on providing services.

In an economic recession, telecommuting and virtual contacts have become an integral part of a survival strategy. The consequences of the psychological shock and the lack of society's preparation for the perception of such cataclysms, of course, have already affected workers' productivity. This is approximately the same as stopping a continuous production process, when restarting and restoring it requires additional funds and time. In order to eliminate such changes, greater flexibility and stability should be given to the culture of labor organization in conditions of self-isolation and remote work.

Working out a new Concept for the future development of Azerbaijan undoubtedly involves the changing realities in the post-coronavirus period to be taken into account. In this regard, we can agree with the opinion of the UN Secretary General Antonio Guterres, set forth on March 26, 2020, during the extraordinary G20 Virtual Leaders Summit on the COVID-19 pandemic, where he said: "We must respond decisively, innovatively and together to suppress the spread of the virus and address the socioeconomic devastation that COVID-19 is causing in all regions" (Guterres, 2020).

\section{Conclusion}

Based on the above, several conclusions can be formulated on the transformation of the conditions of socio-economic development of the country in the new realities:

1. In the post-coronavirus world, as the real course of change has confirmed, the technological basis for building relationships will play an extremely important role. At the same time, expanding the ability to connect to the main communications operating system will largely depend on the availability of various applications.
2. In the changing realities of modernity, the head of state can optimize a new strategy for future development, in which improving the welfare of citizens will remain the main task of the socioeconomic development of the republic.

3. In order to revive the economy, the opening of external borders should be consistent with the removal of restrictions on relations within the internal borders. Accordingly, the construction of new transport and communication systems should be continued.

4. Emphasis should be placed on the choice of "growth poles" in working out a new Concept for the future development of the republic. The selection of such centers and the promotion of their development will contribute to solving the problem of decentralization of the economy of the republic.

5. When developing programs for organizing new territorial and economic entities (agricultural and industrial parks, free trade and economic zones, extended platforms, etc.), priority should be given to peripheral regions, which will help to level out territorial differences in the scale of socio-economic development of the regions of the country.

\section{References}

"Azərbaycan 2020: gələcəyə baxiş" inkişafkonsepsiyasi (Eng. Development concept "Azerbaijan 2020: a look into the future"), 2012, https://president.az/files/future_az.pdf (accessed 15 June 2020).

2020-ci ilin yanvar-may aylarında Ümumi Daxili Mehsul istehsalı (Eng. Gross Domestic Product in January-May 2020), 2020, Azərbaycan Respublikası Dövlət Statistika Komitəsi, https://www.stat.gov.az/news/index.php?id=4609asıdır (accessed 12 June 2019).

Bloom D., 2020, Pandemic, Downturn To Cost Entertainment Industry $\$ 160$ Billion In Growth Over 5 Years, Forbes 21.05.2020, https://www.forbes.com/sites/dbloom/2020/ 05/21/entertainment-industry-160-billion-lost-growth -ampere-theaters-advertising-streaming/\#42d2d0 b77d95 (accessed 09 June 2020).

Brief\#2: Putting the UN framework for socio-economic response to COVID-19 into action: insights, 2020, United Nations, https://reliefweb.int/report/world/brief-2-putting-unframework-socio-economic-response-covid-19-actioninsights-june-2020 (accessed 28 October 2020)

COVID-19 to Plunge Global Economy into Worst Recession since World War II, 2020, World Bank Report "Global Economic Prospects", https://www.worldbank.org/en/news/pressrelease/2020/06/08/covid-19-to-plunge-global-economy-into-worst-recession-since-world-war-ii (accessed 11 June 2020). 
Fung A., 2020, A new civic federalism, [in:] Coronavirus Will Change the World Permanently. Here's How, POLITICO Magazine, https://www.politico.com/news/magazine/2020/03/19/coronavirus-effect-economy-life-society-analysis-covid-135579 (accessed 02April 2020).

Galvani A.P., Lei X., Jewell N.P., 2003, Severe acute respiratory syndrome: temporal stability and geographic variation in case-fatality rates and doubling times, Emerging Infectious Diseases, 9(8), 991-994, doi: 10.3201/eid0908.030334

Gumel A.B., Ruan S., Day T., Watmough J., Brauer F., van der Driessche P., Gabrielson D., Bowman C., Alexander M.E., Ardal S., Wu J., Sahai B.M., 2004, Modelling strategies for controlling SARS outbreaks, Proceedings of the Royal Society B: Biological Sciences, 271(1554), 2223-2232. doi: 10.1098/rspb.2004.2800

Guterres A., 2020, "The recovery from the COVID-19 crisis must lead to a different economy". Launch of report on socioeconomic impacts of COVID-19, United Nations Covid-19 Response, https://www.un.org/en/un-coronaviruscommunications-team/launch-report-socio-economicimpacts-covid-19 (accessed 04 April 2020).

Kent E., 2020, Coronavirus Outbreak Forces Cancellation of Multiple Esports Events, Eurogamer, https://www.eurogamer. net/articles/2020-01-30-coronavirus-outbreak-forcescancellation-of-multiple-esports-events (accessed 28 October 2020).

Keogh-Brown M.R., Wren-Lewis S., Edmunds W.J., Beutels P., Smith R.D., 2010, The possible macroeconomic impact on the UK of an influenza pandemic, Health Economics, 9(11), 1345-1360. doi: 10.1002/hec.1554

Knieps S., 2020, Will COVID-19 turn Germany's export-oriented economy into a weakness?, Euroactiv, www.euractiv. comhttps://www.euractiv.com/section/economy-jobs/ news/will-covid-19-turn-germanys-export-orientedeconomy-into-a-weakness/ (accessed 23 October 2020).

Lipsitch M., Cohen T., Cooper B., Robins J.M., Ma S., James L., Gopalakrishna G., Chew S.K., Tan Ch.Ch., Samore M.H., Fishman D., Murray M., 2003, Transmission dynamics and control of severe acute respiratory syndrome, Science, 300(5627), 1966-1970. doi: 10.1126/science.1086616

Nicola M., O'Neill N., Sohrabi C., Khan M., Agha M., Agha R., 2020, Evidence Based Management Guideline for the COVID-19 Pandemic - Review article, International Journal of Surgery, 77, 206-216. doi: 10.1016/j.ijsu.2020.04.001

The Order of the President of the Republic of Azerbaijan on a number of measures to reduce the negative impact of the coronavirus pandemic (COVID-19), 2020, Official web-site of President of the Republic of Azerbaijan Ilham Aliyev, https://en.president.az/documents/orders (accessed 14 June 2020).

Wang J., McMichael A.J., Meng B., Becker N.G., Hab W., Glass K., Wu J., Liu X., Liu J., Li J., Li X., Zheng X., 2006, Spatial dynamics of an epidemic of severe acute respiratory syndrome in an urban area, Bulletin of the World Health Organization, 84(12), 965-968, doi: 10.2471/blt.06.030247

Wilson J., 2020, The economic impact of coronavirus: analysis from Imperial experts, Imperial College London, https:// www.imperial.ac.uk/news/196514/the-economic-im- pact-coronavirus-analysis-from/ (accessed 02 November 2020).

Yu H.-L., Kolovos A, Christakos G., Chen J.-Ch., Warmerdam S., Dev B., 2007, Interactive spatiotemporal modelling of health systems: the SEKS-GUI framework, Stochastic Environmental Research and Risk Assessment, 21(5), 555-572. doi: 10.1007/s00477-007-0135-0

Zelcer M., 2020, Kto poslednij? Kakie strany vyjdut iz krizisa pozže drugih (Eng. Who is last? Which countries will emerge from the crisis later than others), Forbes 25.05.2020. https://www.forbes.ru/biznes/401205-ktoposledniy-kakie-strany-vyydut-iz-krizisa-pozzhe-drugih (accessed 05 June 2020). 